Dementia

and Geriatric

Cognitive Disorders
Dement Geriatr Cogn Disord 2006;21:88-96

DOI: $\underline{10.1159 / 000090224}$
Accepted after revision: September 7, 2005 Published online: December 9, 2005

\title{
The Efficacy of Omega-3 Fatty Acids on Cognitive Function in Aging and Dementia: A Systematic Review
}

\author{
Amalia M. Issa ${ }^{a, b}$ Walter A. Mojica $^{a}$ Sally C. Morton ${ }^{a}$ Shana Traina a, b, c \\ Sydne J. Newberry ${ }^{a}$ Lara G. Hilton ${ }^{a}$ Rena H. Garland ${ }^{a}$ \\ Catherine H. MacLean ${ }^{a, c, d}$ \\ The Southern California Evidence-Based Practice Center - ${ }^{a}$ RAND Health, Santa Monica, Calif., Schools of \\ ${ }^{b}$ Public Health and ${ }^{\mathrm{c}}$ Medicine, University of California, ${ }^{\mathrm{d}}$ The Greater Los Angeles VA Medical Center, \\ Los Angeles, Calif., USA
}

\section{Key Words}

Omega-3 fatty acids - Treatment of dementia .

Alzheimer's disease $\cdot$ Cognitive function in normal aging

\begin{abstract}
We systematically reviewed the published literature on the effects of omega- 3 fatty acids on measures of cognitive function in normal aging, incidence and treatment of dementia. Computerized databases were searched for published literature to identify potentially relevant studies with the intent to conduct a meta-analysis. We screened 5,865 titles, reviewed 497 studies of which 49 underwent a detailed review, and found 5 studies that pertained to our objectives. We included controlled clinical trials and observational studies, including prospective cohort, case-control, and case series designs; we excluded case reports. We had no language restrictions. We abstracted data on the effects of omega-3 fatty acids
\end{abstract}

The views expressed in this article are those of the authors and do not necessarily reflect those of the Agency for Healthcare Research and Quality or the U.S. Department of Health and Human Services.

\section{KARGER}

Fax +4161306 1234 E-Mail karger@karger.ch www.karger.com

\section{(C) 2006 S. Karger AG, Basel}

$1420-8008 / 06 / 0212-0088 \$ 23.50 / 0$

Accessible online at:

www.karger.com/dem and on study design, relevant outcomes, study population, source, type, amount, and duration of omega- 3 fatty acid consumption, and parameters of methodological quality. A single cohort study has assessed the effects of omega-3 fatty acids on cognitive function with normal aging and found no association for fish or total omega-3 consumption. In four studies that assessed the effects of omega- 3 fatty acids on incidence and treatment of dementia, a trend in favor of omega-3 fatty acids (fish and total omega-3 consumption) toward reducing risk of dementia and improving cognitive function was reported. The available data are insufficient to draw strong conclusions about the effects of omega- 3 fatty acids on cognitive function in normal aging or on the incidence or treatment of dementia. However, limited evidence suggests a possible association between omega- 3 fatty acids and reduced risk of dementia.

Copyright (C) 2006 S. Karger AG, Basel

\section{Introduction}

Prevalence rates for all dementias including Alzheimer's disease (AD) in the U.S. are approximately 5-10\% for individuals aged $65-85$ years old, and $25-45 \%$ for 
those older than 85 years old $[1,2]$. Currently there are about four million people in the U.S. with AD, the most common type of dementia, and this number is expected to double by the year $2050[2,3]$.

There is increasing interest and focus on efforts aimed at identifying modifiable risk factors, including preventative dietary interventions. Various animal [4-6] and human studies [7, 8] have suggested a role for omega-3 fatty acids as a possible preventative strategy for dementia. However, these studies have reported mixed results. A number of dietary supplements with omega -3 fatty acids that claim to be neuroprotective have appeared on the market and several reports in the popular media claim that omega-3 fatty acid supplementation can prevent AD. Indeed, many Internet websites [e.g., 9, 10] promote and/or sell omega-3 fatty acids for dementia. Fish consumption is also increasingly recommended for older adults. However, mercury contamination of fish may be associated with worse performance on some cognitive tasks [11]. There is, therefore, an urgent need to determine whether sufficient good quality evidence exists regarding the health benefits of omega -3 fatty acids as a dietary intervention for cognitive function in aging, and in dementia. However, to the best of our knowledge, the evidence for consuming omega- 3 fatty acids as a modifiable risk factor for dementia has not yet been systematically synthesized. A systematic literature review was performed in order to determine whether sufficient evidence exists to substantiate claims of a health benefit for omega-3 fatty acids on cognitive function in normal aging and in dementia.

\section{Methods}

This study was part of a larger systematic review of the literature on the effects of intake of omega-3 fatty acids on neurological disorders [12], and as a result, our initial search of the literature was broad. This report deals with the effects of omega- 3 fatty acids on cognitive function in normal aging of older adults and on the incidence and treatment of dementia.

\section{Study Identification}

We searched Medline (1966-2003), PreMedline (December 2003), EMBASE (1980-2003), Cochrane Central Register of Controlled Trials (4th Quarter, 2003), dissertation abstracts (18612003) using the Ovid interface, and CAB Health (1973-2003) using SilverPlatter. Additional articles were identified by scanning the references of relevant literature. The search terms used were broad and focused on identifying any relevant article dealing with the conditions of interest in human subjects. Our search was not restricted by language of publication or study design in order to increase specificity. Two of the investigators (W.A.M. and A.M.I.) who were blinded to author and source information (i.e. journal and institution) independently reviewed titles and abstracts. The full text of any articles that were flagged as relevant by either of the two reviewers was obtained for further review. Our objective at this initial stage of screening was to identify articles that described studies about the effects of omega- 3 fatty acids on cognitive function with normal healthy aging or on dementia in human subjects. The full text of any articles for which it was not possible to determine relevance from the title and/or abstract was also retrieved for further review. At this stage, only titles and/or abstracts that clearly did not meet these criteria for inclusion were rejected.

\section{Study Selection}

Any retrieved articles were independently reviewed by the two investigators (W.A.M. and A.M.I.) using a structured screening form in order to determine whether they should be accepted for further review. Reviewers were not blinded to journal or authors at this stage. The following inclusion criteria were used to select studies for further detailed review: (1) the study reported research on human subjects; (2) the study design was any of the following: controlled clinical trials (randomized or nonrandomized), prospective cohort studies, case-control studies, and case series; (3) studies had to describe a difference in omega-3 fatty acid content between study arms (case series were excluded from this criterion), and (4) studies had to describe the effect of omega-3 fatty acids on any of the following outcomes: cognitive function with normal aging, incidence of dementia or treatment of dementia. Cross-sectional studies and case reports were excluded. The reviewers resolved any disagreements by consensus. Articles were not masked.

\section{Data Extraction and Analysis}

Two of the investigators (W.A.M. and A.M.I.) independently abstracted detailed data onto a structured specialized quality review form (QRF) from all the studies that met our screening criteria. Any differences were resolved by consensus. Several outside scientists were consulted to complete QRFs for foreign language articles.

Data were collected from each article for study design, the outcomes of interest, study sample characteristics, details on the intervention, such as the dose, frequency, and duration, the elapsed time between the intervention and outcome measurements, and the type of outcome measures (tables 1 and 2).

Information about the methodological quality of the studies was also abstracted. To evaluate the quality and execution of clinical trials, data were also collected about the randomization, blinding, withdrawals and dropouts, and concealment of allocation. Jadad scores were used to assess the quality of the randomized controlled trials [13]. For observational studies, data were collected about the validity of ascertainment of cases and exposure, description of withdrawals and dropouts, and adjustment for confounders and blinded assessment of exposure and case status when ascertaining case and exposure status, respectively [14, 15]. Data about the methodologic quality of the cohort studies are presented in table 1 and data regarding the quality of the randomized clinical trial (RCT) are presented in table 2 .

\section{Data Analysis}

Because of the heterogeneity among studies, too few studies met the inclusion criteria, and as a result, it was not possible to perform a meta-analysis (pooled statistical analyses). The overall effect of 
Table 1. Evidence table of the effects of omega-3 fatty acids on cognitive function and dementia in cohort studies

\begin{tabular}{|c|c|c|c|c|c|}
\hline $\begin{array}{l}\text { First author, year, } \\
\text { cohort }\end{array}$ & Study characteristics & $\begin{array}{l}\text { Dura- } \\
\text { tion } \\
\text { years }\end{array}$ & Eligibility criteria & Disease, ascertainment & $\begin{array}{l}\text { Funding source, quality, } \\
\text { applicability }\end{array}$ \\
\hline $\begin{array}{l}\text { Barberger-Gateau, } \\
2002 \text { [17] } \\
\text { PAQUID Study }\end{array}$ & $\begin{array}{l}\text { Sample size, people/person } \\
\text { years: } 1,416 / \mathrm{NR} \\
\text { Age, mean/range, } \\
\text { years: NR/68-99 } \\
\text { Race: NR } \\
\text { Males, \%: NR } \\
\text { Sites: } 1 \\
\text { Location: France }\end{array}$ & 7 & $\begin{array}{l}\text { Inclusion: age }=68 / \text { normal } \\
\text { cognition/living at home } \\
\text { Exclusion: dementia }\end{array}$ & $\begin{array}{l}\text { Disease: dementia } \\
\text { Ascertainment: MMSE; } \\
\text { neurological exam }\end{array}$ & $\begin{array}{l}\text { Funding source: industry and } \\
\text { private } \\
\text { Quality: } \\
\text { adjustment for confounders: } \mathrm{Y} \\
\text { blinding of exposure/outcome: } \mathrm{N} \\
\text { valid ascertainment of outcome: } \mathrm{Y} \\
\text { valid ascertainment of exposure: NR } \\
\text { exposure before outcome: } \mathrm{Y} \\
\text { selection bias: N } \\
\text { description of withdrawals and } \\
\text { dropouts: } \mathrm{Y}\end{array}$ \\
\hline $\begin{array}{l}\text { Kalmijn, } \\
1997[16] \\
\text { Zutphen Elderly } \\
\text { Study }\end{array}$ & $\begin{array}{l}\text { Sample size, people/person } \\
\text { years: } 818 / \mathrm{NR} \\
\text { Age, mean/range, } \\
\text { years: NR/69-89 } \\
\text { Race: NR } \\
\text { Males, \%: } 100 \\
\text { Sites: } 1 \\
\text { Location: Netherlands }\end{array}$ & 3 & $\begin{array}{l}\text { Inclusion: NR } \\
\text { Exclusion: NR }\end{array}$ & $\begin{array}{l}\text { Disease: cognitive } \\
\text { function, normal aging } \\
\text { and incidence of dementia } \\
\text { Ascertainment: clinical } \\
\text { exam; MMSE }\end{array}$ & $\begin{array}{l}\text { Funding source: government } \\
\text { Quality: } \\
\text { adjustment for confounders: } \mathrm{Y} \\
\text { blinding of exposure/outcome: } \mathrm{N} \\
\text { valid ascertainment of outcome: } \mathrm{Y} \\
\text { valid ascertainment of exposure: } \mathrm{Y} \\
\text { exposure before outcome: } \mathrm{Y} \\
\text { selection bias: } \mathrm{N} \\
\text { description of withdrawals and } \\
\text { dropouts: } \mathrm{Y}\end{array}$ \\
\hline $\begin{array}{l}\text { Kalmijn, } \\
1997[19] \\
\text { Rotterdam } \\
\text { Cohort }\end{array}$ & $\begin{array}{l}\text { Sample size, people/person } \\
\text { years: } 5,386 / \mathrm{NR} \\
\text { Age, mean/range, } \\
\text { years: } 67.7 / \mathrm{NR} \\
\text { Race: NR } \\
\text { Males, \%: } 41 \\
\text { Sites: } 1 \\
\text { Location: Netherlands }\end{array}$ & 2.1 & $\begin{array}{l}\text { Inclusion: residents of a } \\
\text { suburb in Rotterdam, } \\
\text { age > } 55 \text { years } \\
\text { Exclusion: CAMDEX score } \\
\text { below } 80 \text {; illogical answers to } \\
\text { food pattern questionnaire }\end{array}$ & $\begin{array}{l}\text { Disease: dementia } \\
\text { Ascertainment: medical } \\
\text { records or medical } \\
\text { examination }\end{array}$ & $\begin{array}{l}\text { Applicability: II } \\
\text { Funding source: government } \\
\text { Quality: } \\
\text { adjustment for confounders: } \mathrm{Y} \\
\text { blinding of exposure/outcome: NR } \\
\text { valid ascertainment of outcome: } \mathrm{Y} \\
\text { valid ascertainment of exposure: } \mathrm{Y} \\
\text { exposure before outcome: } \mathrm{Y} \\
\text { selection bias: N } \\
\text { description of withdrawals and } \\
\text { dropouts: } \mathrm{Y}\end{array}$ \\
\hline $\begin{array}{l}\text { Morris, } \\
2003 \text { [18] } \\
\text { Chicago Health } \\
\text { and Aging Project }\end{array}$ & $\begin{array}{l}\text { Sample size, people/person } \\
\text { years: } 815 / \mathrm{NR} \\
\text { Age, mean/range, } \\
\text { years: } 73 / \mathrm{NR} \\
\text { Race: Caucasian and Black } \\
\text { Males, \%: } 39 \\
\text { Sites: } 1 \\
\text { Location: U.S. }\end{array}$ & 3.9 & $\begin{array}{l}\text { Inclusion: normal cognition } \\
\text { Exclusion: NR }\end{array}$ & $\begin{array}{l}\text { Disease: AD } \\
\text { Ascertainment: NINCDS } \\
\text { criteria, neurological exam }\end{array}$ & $\begin{array}{l}\text { Applicability: I } \\
\text { Funding source: government } \\
\text { Quality: } \\
\text { adjustment for confounders: } \mathrm{Y} \\
\text { blinding of exposure/outcome: } \mathrm{Y} \\
\text { valid ascertainment of outcome: } \mathrm{Y} \\
\text { valid ascertainment of exposure: } \mathrm{Y} \\
\text { exposure before outcome: } \mathrm{Y} \\
\text { selection bias: } \mathrm{N} \\
\text { description of withdrawals and } \\
\text { dropouts: } \mathrm{Y}\end{array}$ \\
\hline
\end{tabular}

NR = Not reported; PAQUID = Personnes Agées QUID Study; CAMDEX = Cambridge Examination for Mental Disorders of the Elderly; NINCDS = National Institute of Neurological and Communicative Disorders and Stroke.

omega- 3 fatty acids across the studies and the unit of analysis for omega-3 fatty acid consumption, i.e. fish, total omega-3 fatty acids, docosahexaenoic acid (DHA), eicosapentaenoic acid (EPA), or alpha linolenic acid (ALA) are described. The point estimates and statistical testing that were described in the original studies are summarized.

\section{Results}

The initial broad search of the literature on the effects of omega- 3 fatty acids on neurological disorders yielded 5,865 citations. Two of the investigators (W.A.M. and A.M.I.) identified 497 of these article titles and abstracts to be relevant to the questions related to the effects of 
Table 2. Evidence table of the effects of omega-3 fatty acids on the treatment of dementia in an RCT

\begin{tabular}{|c|c|c|c|c|c|c|c|c|}
\hline $\begin{array}{l}\text { First author } \\
\text { year }\end{array}$ & Study characteristics & $\begin{array}{l}\text { Study } \\
\text { design }\end{array}$ & $\begin{array}{l}\text { Dura- } \\
\text { tion } \\
\text { months }\end{array}$ & $\begin{array}{l}\text { Eligibility } \\
\text { criteria }\end{array}$ & $\begin{array}{l}\text { Concurrent } \\
\text { disease, } \\
\text { condition, } \\
\text { medication }\end{array}$ & Arm & $\begin{array}{l}\text { Interventions, } \\
\text { dosage, duration }\end{array}$ & Quality \\
\hline \multirow[t]{2}{*}{$\begin{array}{l}\text { Terano, } \\
1999 \text { [20] }\end{array}$} & \multirow{2}{*}{$\begin{array}{l}\text { Sample size, } \\
\text { people/person years: 20/NR } \\
\text { Age, mean/range, years: 83/NR } \\
\text { Race: NR } \\
\text { Males, \%: NR } \\
\text { Sites: } 1 \\
\text { Location: Japan }\end{array}$} & \multirow[t]{2}{*}{$\mathrm{RCT}$} & \multirow[t]{2}{*}{12} & \multirow[t]{2}{*}{$\begin{array}{l}\text { Inclusion: other } \\
\text { dementia } \\
\text { Exclusion: NR }\end{array}$} & \multirow[t]{2}{*}{ NR } & 1 & $\begin{array}{l}\text { Intervention: standard } \\
\text { hospital diet } \\
\text { Dosage: NR }\end{array}$ & $\begin{array}{l}\text { Jadad: } 1 \\
\text { Concealment of } \\
\text { allocation: NR } \\
\text { Funding source: NR }\end{array}$ \\
\hline & & & & & & 2 & $\begin{array}{l}\text { Intervention: DHA } \\
\text { Dosage: } 4.3 \mathrm{~g} / \text { day } \\
\text { Duration: } 12 \text { months }\end{array}$ & \\
\hline
\end{tabular}

omega-3 fatty acids on neurological disorders. However, most of these did not specifically deal with cognitive function in aging or dementia. Forty-nine studies were identified that deal with the effects of omega- 3 fatty acids on cognitive function in normal aging or dementia, and that passed the preliminary screening criteria. These studies were further reviewed using the QRF. We further excluded studies from our final analysis set based on study design and whether the study assessed the difference in omega-3 content across study arms. Among the 49 studies reviewed with the QRF, 44 studies were rejected because they did not meet our study design criteria or did not distinguish between omega- 3 fatty acid content between the study arms. Results from this initial literature search are detailed in figure 1.

In total, five studies were identified that described the effects of omega-3 fatty acids on cognitive function with aging or dementia; one was an RCT and four were cohort studies. The characteristics of the studies that were analyzed are described in table 3.

\section{Effects of Omega-3 Fatty Acid Intake on Cognitive \\ Function in Normal Aging}

A single prospective cohort study [16] that evaluated the effects of omega-3 fatty acids on cognitive function in normal aging was identified. This study investigated the association between omega- 3 fatty acids and cognitive function in an original cohort of 939 communitydwelling men living in the Dutch town of Zutphen, who were participants in the Zutphen Elderly Study, a longitudinal study on risk factors for various chronic diseases. Data about dietary intake were collected by trained interviewers in 1985 and 1993, and data about cognitive function were collected in 1990 and 1993. Complete dietary information was collected on 476 men, and complete in- formation regarding cognitive function was collected on 342 men. The relationship between both fish consumption and total omega-3-fatty acid consumption with both cognitive impairment and cognitive decline was assessed. Cognitive impairment was defined as a Mini-Mental State Examination (MMSE) score of $\leq 25$. Cognitive decline was defined as a drop of more than two points in the MMSE over a 3-year period, which corresponds to the 15 th percentile of change. Compared with no fish consumption, fish consumption was inversely associated with cognitive impairment in crude analyses, but not after adjustment for multiple variables (table 4). Fish consumption was also inversely associated with development of cognitive decline, though not significantly so (table 4). Total omega-3 fatty acid consumption was not related to cognitive impairment or cognitive decline. A dose effect was observed for omega-3 fatty acid consumption and cognitive impairment on unadjusted analyses ( $p$ for trend $=0.9)$, but not on adjusted analyses. No dose effect was found with omega- 3 fatty acid consumption and cognitive decline.

This study adjusted for confounders, used valid methods to determine exposure and outcomes, ascertained that exposure occurred before outcome measurement, and described withdrawals and dropouts.

\section{Effects of Omega-3 Fatty Acid Intake on the \\ Incidence of Dementia}

Three prospective cohort studies [17-19] that evaluated the effect of omega-3 fatty acids on the incidence of dementia were identified (table 4). All three of the studies assessed the incidence of dementia relative to fish consumption; one also assessed risk relative to total omega3 fatty acid consumption, and relative to ALA, EPA, and DHA consumption, respectively [18]. Fish consumption 


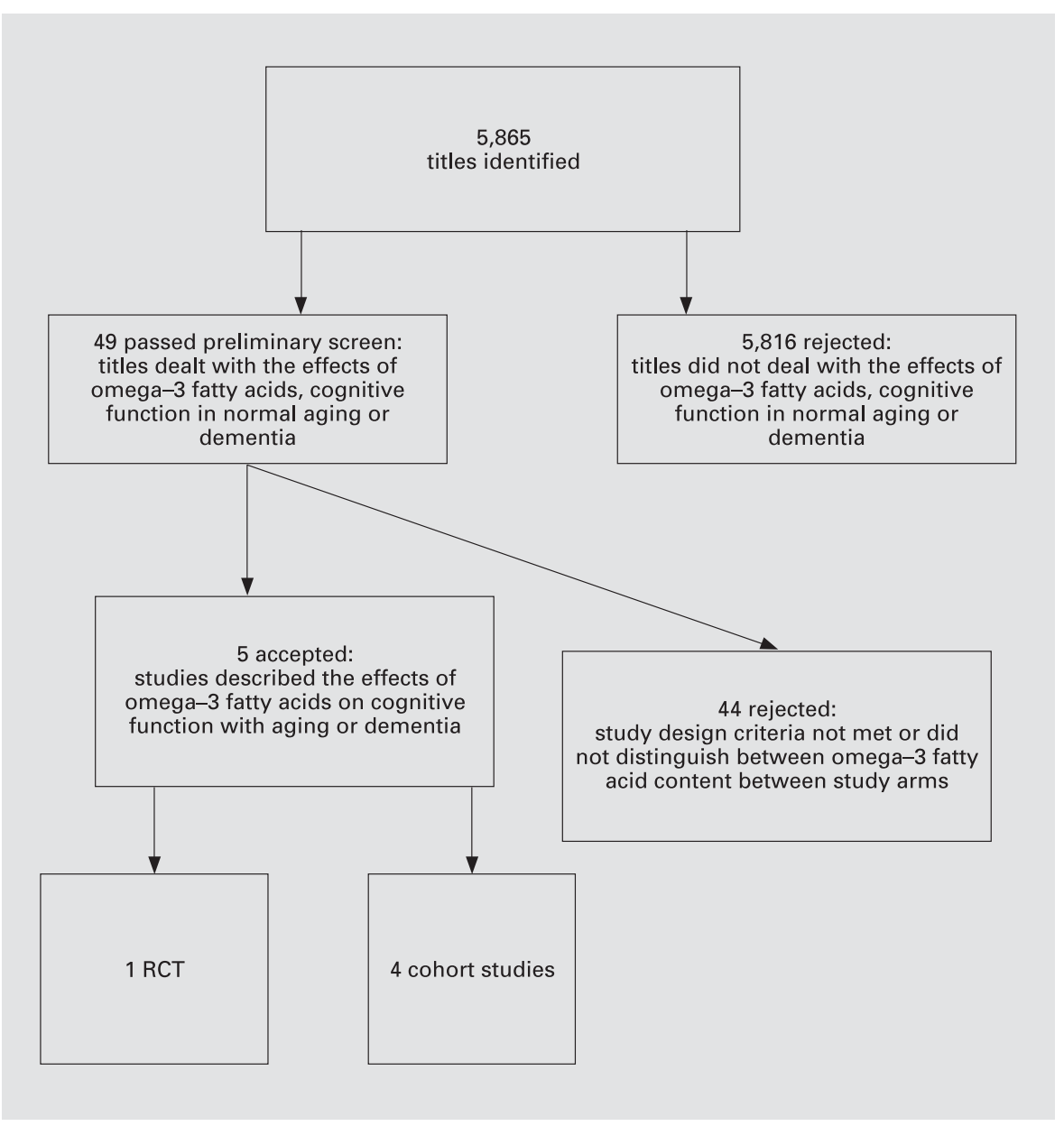

Fig. 1. Literature flow.

Table 3. Characteristics of identified studies on the effects of omega- 3 fatty acids on cognitive function in normal aging and dementia

\begin{tabular}{|c|c|c|c|c|c|c|c|}
\hline $\begin{array}{l}\text { Authors } \\
\text { year }\end{array}$ & $\begin{array}{l}\text { Study } \\
\text { design }\end{array}$ & Population studied & $\begin{array}{l}\text { Age, years } \\
\text { (mean/range) }\end{array}$ & $\begin{array}{l}\text { Sex } \\
\text { distribution } \\
\% \text { male }\end{array}$ & $\begin{array}{l}\text { Total } \\
\text { sample } \\
\text { size }\end{array}$ & $\begin{array}{l}\text { Study } \\
\text { duration } \\
\text { months }\end{array}$ & $\begin{array}{l}\text { Cognitive outcome } \\
\text { measure(s) }\end{array}$ \\
\hline $\begin{array}{l}\text { Terano et al., } \\
1999[20]\end{array}$ & $\mathrm{RCT}$ & $\begin{array}{l}\text { nursing home residents with vascular } \\
\text { dementia }\end{array}$ & $83 / \mathrm{NR}$ & NR & 20 & 12 & $\begin{array}{l}\text { HDS-R; } \\
\text { MMSE }\end{array}$ \\
\hline $\begin{array}{l}\text { Kalmijn et al., } \\
1997[16]\end{array}$ & cohort & $\begin{array}{l}\text { community-dwelling elderly from the } \\
\text { Zutphen Elderly Study }\end{array}$ & NR/69-89 & $100 \%$ & 939 & 36 & MMSE \\
\hline $\begin{array}{l}\text { Barberger-Gateau } \\
\text { et al., 2002 [17] }\end{array}$ & cohort & $\begin{array}{l}\text { cognitively-normal, community- } \\
\text { dwelling elderly from the PAQUID } \\
\text { Study }\end{array}$ & NR/68-99 & NR & 1,416 & 84 & $\begin{array}{l}\text { incidence of } \\
\text { dementia, } \mathrm{AD} ; \\
\text { vascular dementia }\end{array}$ \\
\hline $\begin{array}{l}\text { Kalmijn et al., } \\
1997[19]\end{array}$ & cohort & $\begin{array}{l}\text { community-dwelling elderly from the } \\
\text { Rotterdam Study }\end{array}$ & $67.7 / \mathrm{NR}$ & $41 \%$ & 5,386 & 25 & $\begin{array}{l}\text { MMSE; } \\
\text { CAMDEX }\end{array}$ \\
\hline $\begin{array}{l}\text { Morris et al., } \\
2003[18]\end{array}$ & cohort & $\begin{array}{l}\text { community-dwelling elderly from the } \\
\text { Chicago Health and Aging Project }\end{array}$ & 73/NR & $39 \%$ & 815 & 46.8 & $\begin{array}{l}\text { battery of standard } \\
\text { cognitive tests } \\
\text { including MMSE }\end{array}$ \\
\hline
\end{tabular}


Table 4. Estimates of effect of omega- 3 fatty acids on cognitive function and dementia in cohort studies by category of omega- 3 consumption



${ }^{\mathrm{a}}$ Hazard ratio; ${ }^{\mathrm{b}}$ age- and sex-adjusted; test for trend; ${ }^{\mathrm{c}}$ median amount; ${ }^{\mathrm{d}}$ authors report that $40 \%$ of participants had $0 \mathrm{~g} / \mathrm{day}$ of intake. 
Table 5. The effect of omega-3 fatty acids on the treatment of dementia in one RCT [20] stratified by outcome

\begin{tabular}{|c|c|c|c|c|}
\hline \multirow[t]{2}{*}{ Study arms } & \multicolumn{4}{|l|}{ Results } \\
\hline & before & $\begin{array}{l}\text { after } 3 \\
\text { months }\end{array}$ & $\begin{array}{l}\text { after } 6 \\
\text { months }\end{array}$ & $\begin{array}{l}\text { after } 12 \\
\text { months }\end{array}$ \\
\hline \multicolumn{5}{|l|}{ Mean scores of $H D S-R$} \\
\hline Standard nursing home diet & 16.3 & 16.7 & 16.7 & 15.3 \\
\hline Standard nursing home diet plus DHA $4.3 \mathrm{~g} /$ day & 17.2 & $20.6^{*}$ & $19.9 *$ & 20.2 \\
\hline \multicolumn{5}{|l|}{ Mean scores of MMSE } \\
\hline Standard nursing home diet & 19.7 & 19.4 & $19.6^{*}$ & 19.1 \\
\hline Standard nursing home diet plus DHA $4.3 \mathrm{~g} /$ day & 20.1 & 21.3 & 22.2 & 21.9 \\
\hline
\end{tabular}

was associated with a significant reduction in the incidence of non-Alzheimer dementia in two studies [17, 19], although in one statistical significance was lost with multivariable adjustment [17] (table 4). Fish consumption was associated with a reduced risk of Alzheimer's dementia in all three of the studies; the association was statistically significant in one [19] and nearly so in the other two $[17,18]$ (table 4$)$. Total omega-3 fatty acid consumption and consumption of DHA were associated with a significant reduction in the incidence of $\mathrm{AD}$; consumption of ALA and EPA were not [18] (table 4). Dose effects were observed for fish in one study [19] and for total omega-3 consumption and DHA in another [18] (p for trend $<0.05$ for each; table 4).

One study assessed whether gender modified the effect of total omega-3 fatty acid consumption or consumption of fish, ALA, EPA, or DHA [18]. Total intake of omega3 fatty acids was protective in females only ( $p$ for interaction $=0.02$ ); gender did not modify the effect of fish, ALA, EPA, or DHA.

Two of the studies $[18,19]$ assessed the influence of covariates on the effect of omega- 3 fatty acids on incidence of dementia. In one study [18], the multivariable relative risks for intakes of total omega-3 fatty acids, DHA, and EPA did not change when adjusted for vitamin E intake, other fat intake and cardiovascular disease. In the same study, multivariable risks for intake of ALA were reported as approximately 1.0 with adjustment for vitamin $\mathrm{E}$ but not affected by adjustment for cardiovascular disease; intake of ALA was strongly protective among people with the apolipoprotein E4 genotype $(\mathrm{RR}=0.08$ per natural log of increase (in milligram) in ALA, $p=0.02$ ). In the other study [19], estimates of relative risk did not change with adjustment for cigarette smoking, alcohol consumption, fiber consumption, anti- oxidant intake, stroke, myocardial infarction, or serum total and high-density lipoprotein cholesterol.

Among these three studies, all adjusted for confounders, reported using valid methods to ascertain outcomes, and confirmed that the exposure occurred prior to the outcome.

\section{Effects of Omega-3 Fatty Acid Intake on the}

Treatment of Dementia

One study [20] was identified that assessed omega-3 fatty acids as treatment for dementia. This RCT assessed the effect of supplementation with DHA on cognitive function among 20 elderly nursing home residents with vascular dementia. Cognitive functioning was evaluated using Hasegawa's Dementia Rating Scale (HDS-R) and MMSE scores at baseline, after 3, 6, and 12 months. Baseline HDS-R and MMSE scores were 15-22, consistent with mild to moderate dementia. HDS-R and MMSE scores improved in the DHA-treated group but not among patients who were not treated with DHA (table 5). Comparisons between groups were significant at 3 and 6 months for the HDS-R and at 6 months for the MMSE.

To assess the quality of this study, a summary quality score (A, B, or C) was applied based on the combination of the Jadad [13] instrument and reporting of concealment of allocation to this single RCT. Although this trial is described as randomized, the randomization procedure is not described as double blind, and there is no description regarding blinding, withdrawals or dropouts. This study, therefore, scored a summary quality score of $\mathrm{C}$ (Jadad score $=1$; concealment of allocation was not reported; table 2) and can be considered of poor quality. 


\section{Discussion}

Although the lay press and commercial advertisements have purported that omega -3 fatty acids are beneficial for cognitive function and the treatment of dementia, we were unable to find strong evidence to support these claims. A detailed systematic search of the literature identified only five articles that informed these topics. The data in these studies are insufficient to draw conclusions about the effects of omega- 3 fatty acids on cognitive function in normal aging or on the treatment of dementia. However, they do suggest a possible association between omega- 3 fatty acids and reduced risk of dementia, but this finding must be confirmed in other studies before strong conclusions can be drawn.

Although there are too few studies to draw firm conclusions about the effects of omega- 3 fatty acids on the incidence, the fact that each of the three prospective cohort studies [17-19] demonstrated that fish consumption was associated with a reduced risk of Alzheimer's dementia, makes it less likely that these findings are spurious. Furthermore, these findings are consistent with animal models and some pathophysiological theories of dementia. Work in animal models has reported superior learning and memory in animals fed omega- 3 fatty acids compared with control animals $[4,5]$. In a transgenic mouse model, dietary DHA improved memory, increased synapse density and decreased $A \beta$ toxicity, thus providing evidence of protection against $\mathrm{AD}$ and cognitive decline [6].

It is important to point out that a major limitation of studies of omega- 3 fatty acids and disease is the lack of standardized methods to measure nutrient levels [21]. Thus, it is possible to report overestimation or underestimation of true associations with outcomes due to errors in measurement of nutrients. Because baseline dietary consumption of omega -3 and omega- 6 fatty acids may influence the effects of supplementation with omega-3 fatty acids, trials of omega- 3 fatty acids should include a baseline assessment of dietary omega -3 and omega -6 fatty acid intake; however, again, few of the studies that we identified did so. Thus, we could not determine true total intakes of omega- 3 fatty acids. Furthermore, the studies we reviewed lacked a uniform or consistent approach to quantifying the type of omega-3 fatty acid. For example, some measured nutrient intake from food frequency questionnaires without reporting type of fish or method of preparation; other studies defined omega -3 fatty acid supplements. This issue will increasingly become important in the design of future studies of omega-3 fatty acids and disease.
It is also important to note that in observational studies, it is not possible to control exposure [22], which can lead to confounding [23]. Observational studies focused on repeated measures of diet for long-term intake, and subgroup analysis among persons with cardiovascular conditions (including history of stroke or myocardial infarction) also need to be performed in order to determine whether change in diet among these subgroups results in confounding due to change in dietary intake.

The paucity of evidence in this area suggests that further epidemiological and clinical research remains to be done before conclusions can be drawn or policy recommendations can be made regarding the health effects of omega-3 fatty acids on cognition or prevention of dementia. Because our search methods were comprehensive, this apparent lack of published literature likely represents an actual paucity of research on this topic.

\section{Acknowledgements}

This work was supported by the Agency for Health Care Research and Quality (AHRQ) Contract 290-02-0003. Dr. Issa is an AHRQ awardee. Dr. MacLean is a VA HSR\&D Career Development awardee. The authors would like to thank Paul G. Shekelle, $\mathrm{MD}, \mathrm{PhD}$, for his insightful comments on an earlier draft of the manuscript, and Cony Rolon and Shannon Rhodes for their technical assistance. We thank Di Valentine for providing translation of Italian studies, Takahiro Higashi for providing translation of Japanese studies, Matthius Schonlau for providing translation of German studies, and Grazyna Besser for providing translation of Polish studies. 


\section{References}

1 U.S. General Accounting Office: Alzheimer's Disease: Estimates of Prevalence in the United States (GAO/HEHS-98-16, 1-45). Washington, U.S. General Accounting Office, 1998.

$\checkmark 2$ Hebert LE, Beckett LA, Scherr PA, Evans DA: Annual incidence of Alzheimer disease in the United States projected to the years 2000 to 2050. Alz Dis Assoc Disord 2001;4:169-173.

-3 Haan MN, Wallace R: Can dementia be prevented? Brain aging in a population-based context. Annu Rev Pub Health 2004;25:1-24.

4 Hashimoto M, Hossain S, Shimada T, Sugioka K, Yamasaki H, Fujii Y, Ishibashi Y, Oka J, Shido O: Docosahexaenoic acid provides protection from impairment of learning ability in Alzheimer's disease model rats. J Neurochem 2002;81:1084-1091.

5 Favrelere S, Stadelmann-Ingrand S, Huguet F, De Javel D, Piriou A, Tallineau C, Durand G: Age-related changes in ethanolamine glycerophospholipid fatty acid levels in rat frontal cortex and hippocampus. Neurobiol Aging 2000; 21:653-660.

-6 Calon F, Lim GP, Yang F, Morihara T, Teter B, Ubeda O, Rostaing P, Triller A, Salem N Jr, Ashe KH, Frautschy SA, Cole GM: Docosahexaenoic acid protects from dendritic pathology in an Alzheimer's disease mouse model. Neuron 2004;43:633-664.

$\checkmark 7$ Cooper JL: Dietary lipids in the aetiology of Alzheimer's disease: implications for therapy. Drugs Aging 2003;20:399-418.

-8 Friedland R: Fish consumption and the risk of Alzheimer disease: is it time to make dietary recommendations? Arch Neurol 2003;60:923924.
9 http://qualitycounts.com/fpfattyacids.html. Accessed February 10, 2005.

$10 \mathrm{http}$ ://www.discount-vitamins-herbs.net/ health-news27.htm. Accessed February 10, 2005.

11 Weil M, Bressler J, Parsons P, Bolla K, Glass T, Schwartz B: Blood mercury levels and neurobehavioral function. JAMA 2005;293:18751882.

12 MacLean CH, Issa AM, Newberry SJ, Mojica WA, Morton SC, Garland RH, Hilton LG, Traina SB, Shekelle PG: Effects of Omega-3 Fatty Acids on Cognitive Function with Aging, Dementia, and Neurological Diseases. Evidence Report/Technology Assessment No. 114 (Prepared by the Southern California Evidence-Based Practice Center, under contract No. 290-02-0003). Publication No. 05-E011-2. Rockville, Agency for Healthcare Research and Quality, February 2005.

13 Jadad AR, Moore RA, Carroll D, Jenkinson C, Reynolds DJ, Gavaghan DJ, McQuay HJ: Assessing the quality of reports of randomized clinical trials: is blinding necessary? Control Clin Trials 1996; $17: 1-12$.

14 Downs S, Black N: The feasibility of creating a checklist for the assessment of the methodological quality both of randomised and nonrandomised studies of health care interventions. J Epidemiol Community Health 1998; 52:377-384.
15 Saunders L, Soomro G, Buckingham J, Jamtvedt G, Raina P: Assessing the methodological quality of nonrandomized intervention studies. West J Nurs Res 2003;25:223-237.

16 Kalmijn S, Feskens EJ, Launer LJ, Kromhout D: Polyunsaturated fatty acids, antioxidants, and cognitive function in very old men. Am J Epidemiol 1997;145:33-41.

17 Barberger-Gateau P, Letenneur L, Deschamps V, Peres K, Dartigues JF, Renaud S: Fish, meat, and risk of dementia: cohort study. BMJ 2002;325:932-933.

18 Morris MC, Evans DA, Bienias JL, Tangney CC, Bennett DA, Wilson RS, Aggarwal N, Schneider J: Consumption of fish and n-3 fatty acids and risk of incident Alzheimer disease. Arch Neurol 2003;60:940-946.

$>19$ Kalmijn S, Launer LJ, Ott A, Witteman JC, Hofman A, Breteler MM: Dietary fat intake and the risk of incident dementia in the Rotterdam study. Ann Neurol 1997;42:776-782.

20 Terano T, Fujishiro S, Ban T, Yamamoto K, Tanaka T, Noguchi Y, Tamura Y, Yazawa K, Hirayama T: Docosahexaenoic acid supplementation improves the moderately severe dementia from thrombotic cerebrovascular diseases. Lipids 1999;34(suppl):S345-S346.

21 Willet W: Overview of nutritional epidemiology; in Willet W (ed): Nutritional Epidemiology, ed 2. New York, Oxford University Press, 1998, pp 3-17.

-22 Grimes DA, Schulz KF: Cohort studies: marching towards outcomes. Lancet 2002;359:341345.

-23 Grimes DA, Schulz KF: Bias and causal associations in observational research. Lancet 2002;359:248-252. 